\title{
KARAKTERISTIK GOOD CORPORATE GOVERNANCE PADA BANK SYARIAH DAN BANK KONVENSIONAL
}

\author{
Aldira Maradita \\ dira_dita@gmail.com \\ Praktisi Hukum
}

\begin{abstract}
Basically, good corporate governance is the implementation of the vision and mission of Islamic banking. The main point is the reference of this visionis to fulfil the principle of prudence (prudential banking). Meanwhile, point mission is to prepare and implement the concept of risk-based regulation and supervision to ensure the sustainability of Islamic banking operations in accordance with the characteristics that Islamic corporate governance meant that economic activity actually undertake into achieve its goal, both goals hablumminallah and hablumminannas. This is reasonable, because Islamic Corporate Governance has become the soul of all parties involved in the company (stakeholders), the fraud, speculation, insidertrading, or else can be minimized.
\end{abstract}

Key words: GCG, sharia banking, conventional banking.

\begin{abstract}
Abstrak
Pada dasarnya, GCG adalah implementasi visi dan misi perbankan syariah. Poin utama yang menjadi acuan dari visi ini adalah memenuhi prinsip kehati-hatian (prudential banking). Sedangkan, poin misinya adalah mempersiapkan konsep serta melaksanakan pengaturan dan pengawasan berbasis risiko untuk menjamin kesinambungan operasi perbankan syariah yang sesuai dengan karakteristiknya yaitu Islamic Corporate Governance dimaksudkan agar aktivitas ekonomi yang dijalankan benar-benar dapat mencapai tujuannya, baik tujuan hablumminallah dan hablumminanas. Hal ini sangat beralasan, karena apabila Islamic Corporate Governance sudah menjadi jiwa bagi semua pihak yang terlibat di perusahaan (stakeholders), maka kecurangan, spekulasi, insider-trading dan sebagainya akan bisa diminimalisasi
\end{abstract}

Kata kunci: GCG, perbankan syariah, perbankan konvensional. 


\section{Pendahuluan}

Perkembangan kegiatan perbankan saat ini tidak hanya didominasi oleh bankbank konvensional yang sudah lebih dulu ada dan eksis di Indonesia, bank dalam sektor syariahpun saat ini sudah mulai berkembang dan mulai diterima di masyarakat. Perbankan Syariah seperti halnya perbankan pada umumnya merupakan lembaga intermediasi keuangan (financial intermediary institution)yakni lembaga yang melakukan kegiatan menghimpun dana dari masyarakat dalam bentuk kredit atau pembiayaan. Dengan munculnya Undang-Undang Nomor 10 Tahun 1998 tentang Perubahan atas Undang-Undang Nomor 7 Tahun 1992 tentang Perbankan (selanjutnya disebut UU Perbankan), maka bank syariah diakui keberadaannya dalam sistem perbankan di Indonesia. Kaitannya dengan Perbankan Syariah, undang-undang ini lebih memberikan kesempatan bagi perkembangan perbankan syariah di Indonesia, karena undang-undang inilah yang secara tegas membedakan bank berdasarkan prinsip konvensional dan bank berdasarkan prinsip syariah.

Bank yang beroperasi sesuai dengan prinsip-prinsip syariah Islam maksudnya adalah bank yang dalam beroperasinya itu mengikuti ketentuan-ketentuan syariah Islam, khususnya yang menyangkut tata cara bermuamalah secara Islam. Dalam tata cara bermualat itu dijauhi praktik-praktik yang dikhawatirkan mengandung unsur-unsur riba, untuk diisi dengan kegiatankegiatan investasi atas dasar bagi hasil dan pembiayaan perdagangan atau praktik-praktik usaha yang dilakukan di zaman Rasulullah atau bntuk-bentuk usaha yang telah ada sebelumnya, tetapi tidak dilarang oleh beliau. ${ }^{1}$

Pengoperasian bank syariah ini tidak terlepas dengan tuntutan pelaksanaan tata kelola perusahaan yang baik (Good Corporate Governance untuk selanjutnya disebut sebagai GCG). Pemicu utama berkembangnya tuntutan ini diakibatkan oleh krisis yang terjadi di sektor perbankan yang umumnya di dominasi oleh perbankan konvensional pada tahun 1997 yang terus berlangsung hingga tahun 2000. Krisis Perbankan yang melanda Indonesia tersebut bukan sebagai akibat merosotnya nilai tukar rupiah, melainkan karena belum berjalannnya praktek Good Corporate Governance di kalangan perbankan. ${ }^{2}$

Terjadinya pelanggaran batas maksimum pemberian kredit, rendahnya praktek manajemen resiko, tidak adanya transparansi terhadap informasi keuangan kepada nasabah, dan adanya dominasi para pemegang saham dalam mengatur operasional perbankan menyebabkan rapuhnya industri perbankan nasional. Mulai saat itulah tata kelola perusahaan yang baik (Good Corporate Governance/GCG) mengemuka. Dimulai dengan jatuhnya perusahaan-perusahaan di Indonesia yang disebabkan oleh tidak patuhnya manajemen perusahaan terhadap prinsipprinsip GCG. Dengan melaksanakan konsep GCG, diharapkan tercipta citra lembaga yang dapat dipercaya. Artinya ada keyakinan bahwa bisnis perbankan dikelola dengan baik sehingga 2005, h. 33.

2 Firani, "Menjadi Lebih Baik Dengan Good Corporate Governance pada Perbankan", <http://banking. blog.gunadarma.ac.id/2009/04/29/menjadi-lebih-baik-dengan-good-corporate governance-pada-perbankan/>, diunduh 04 November 2009. 
dapat tumbuh secara sehat, kuat dan efisien.

\section{Good Corporate Governance pada Bank Konvensional}

Secara umum dalam UU Perbankan telah diatur ketentuan yang terkait dengan GCG yang kemudian diatur secara khusus didalam PBI No 8/4/PBI/2006 sebagaimana telah diubah dengan PBI No 8/14/PBI/2006 tentang GCG, yangterdiri atas : pertama, uji kelayakan dan kepatutan, (fit and proper test), yang mengatur perlunya peningkatan kompetensi dan integritas manajemen perbankan melalui uji kelayakan dan kepatutan terhadap pemilik, pemegang saham pengendali, dewan komisaris, direksi, dan pejabat eksekutif bank dalam aktivitas pengelolaan bank. Kedua, independensi manajemen bank, dimana para anggota dewan komisaris dan direksi tidak boleh memiliki hubungan kekerabatan atau memiliki hubungan financial dengan dewan komisaris dan direksi atau menjadi pemegang saham pengendali di perusahaan lain. Ketiga, ketentuan bagi direktur kepatutan dan peningkatan fungsi audit bank publik. Dalam standar penerapan fungsi internal audit bank publik, bank diwajibkan untuk menunjuk direktur kepatuhan yang bertanggung jawab atas kepatuhan bank terhadap regulasi yang ada. ${ }^{3}$

\section{Good Corporate Governance pada Bank Syariah}

Penerapan prinsip-prinsip GCG menjadi suatu keharusan bagi sebuah institusi, termasuk di dalamnya institusi bank syariah. Hal ini lebih ditujukan kepada adanya tanggung jawab publik (public accountability) berkaitan dengan kegiatan operasional bank yang diharapkan benarbenar mematuhi ketentuan-ketentuan yang telah digariskan dalam hukum positif. Di samping itu juga berkaitan dengan kepatuhan bank syariah terhadap prinsip-prinsip syariah sebagaimana yang telah digariskan dalam al-Quran, Hadis, dan Ijmak para ulama.

Pengertian GCG sendiri menurut Pasal 1 angka 6 Peraturan Bank Indonesia No.8/4/ PBI/2006 tentang Pelaksanaan Good Corporate Governance Bagi Bank Umum. Disebutkan bahwa good corporate governance adalah tatakelola bank yang menerapkan prinsip-prinsip keterbukaan(transparancy), akuntabilitas(accountability), pertanggungjawaban(responsibility), independensi (independency), dan kewajaran (fairness). Secara umum, fungsi bank syariah sama dengan perbankan konvensional yakni sebagai lembaga intermediasi (intermediary institution) yang mengerahkan dana dari masyarakat dan menyalurkan kembali dana-dana tersebut kepada masyarakat yang membutuhkannya dalam bentuk fasilitas pembiayaan. Karena itu, prinsipprinsip pokok GCG yang dikembangkan secara umum untuk sistem perbankan berlaku pula pada bank syariah. Kelima prinsip pokok GCG diatas dapat dijabarkan sebagai berikut: 1) Prinsip Keterbukaan (transparency). Artinya, bank syariah berkewajiban memberi informasi tentang kondisi dan prospek perbankannya secara tepat waktu, memadai, jelas, dan akurat. Informasi itu juga harus mudah diakses oleh stakeholders sesuai dengan haknya. Hal ini dapat digunakan sebagai dasar bagi mereka untuk menilai reputasi dan tanggung jawab bank syariah; 2) Prinsip

3 Thomas S. Kaihatu, "Good Corporate Governance dan Penerapannya di Indonesia," <http://puslit2.

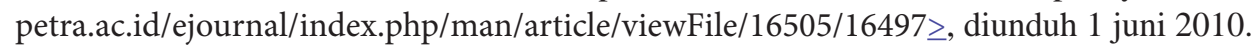


Akuntabilitas, di mana bank syariah harus menetapkan tanggung jawab yang jelas dari setiap komponen organisasi, selaras dengan visi, misi, sasaran usaha, dan strategi perusahaan. Setiap komponen organisasi mempunyai kompetensi sesuai dengan tanggung jawab masing-masing. Selain itu, bank harus memastikan ada dan tidaknya check and balance dalam pengelolaan bank. Bank harus memiliki ukuran kinerja dari semua jajarannya berdasarkan ukuran yang disepakati secara konsisten, sesuai dengan nilai perusahaaan (corporate values), sasaran usaha, strategi bank, serta memiliki reward and punishment system; 3) Prinsip Tanggung Jawab (responsibility). Artinya, bank syariah harus memegang prinsip prudential banking practices. Prinsip ini harus dijalankan sesuai dengan ketentuan yang berlaku, agar operasional perbankan syariah tetap berjalan sesuai dengan yang diharapkan. Bank pun harus mampu bertindak sebagai good corporate citizen (perusahaan yang baik); 4) Prinsip Independensi. Bank syariah harus mampu menghindari dominasi yang tidak wajar oleh stakeholders. Pengelola bank tidak boleh terpengaruh oleh kepentingan sepihak. Bank syariah harus menghindari segala bentuk benturan kepentingan (conflict of interest); 5) Prinsip Keadilan (fairness), artinya bank syariah harus memperhatikan kepentingan seluruh stakeholders berdasarkan azas kesetaraan dan kewajaran (equal treatment). Namun, bank juga perlu memberi kesempatan kepada stakeholders untuk memberi masukan dan saran demi kemajuan bank syariah.

GCG pada lembaga keuangan, khususnya bank memiliki keunikan bila dibandingkan governance pada lembaga keuangan non-bank. Hal ini lebih disebabkan oleh kehadiran deposan sebagai suatu kelompok stakeholders yang kepentingannya harus diakomodir dan dijaga. Sementara itu khusus dalam perbankan syariah dikenal adanya prinsip-prinsip syariah yang mendukung bagi terlaksananya prinsip GCG dimaksud, yakni keharusan bagi subjek hukum termasuk bank untuk menerapkan prinsip kejujuran (shiddiq), edukasi kepada masyarakat (tabligh), kepercayaan (amanah), dan pengelolaan secara profesional (fathanah). Shiddiq berartimemastikan bahwa pengelolaan bank syariah dilakukan dengan moralitas yang menjunjung tinggi nilai kejujuran. Dengan nilai ini pengelolaan dana masyarakat akan dilakukan dengan mengedepankan cara-cara yang diperkenankan (halal) serta menjauhi caracara yang meragukan (subhat) terlebih lagi yang bersifat dilarang (haram). Tabligh berartisecara berkesinambungan melakukan sosialisasi dan mengedukasi masyarakat mengenai prinsipprinsip, produk dan jasa perbankan syariah. Dalam melakukan sosialisasi sebaiknya tidak hanya mengedepankan pemenuhan prinsip syariah semata, tetapi juga harus mampu mengedukasi masyarakat mengenai manfaat bagi pengguna jasa perbankan syariah. Amanah berarti menjaga dengan ketat prinsip kehati-hatian dan kejujuran dalam mengelola dana yang diperoleh dari pemilik dana (shahibul maal) sehingga timbul rasa saling percaya antara pihak pemilik dana dan pihak pengelola dana investasi (mudharib). Sedangkan Fathanah berarti memastikan bahwa pengelolaan bank dilakukan secara profesional dan kompetitif sehingga menghasilkan keuntungan maksimum dalam tingkat risiko yang ditetapkan oleh bank. Termasuk di dalamnya adalah pelayanan yang penuh dengan kecermatan dan kesantunan (ri'ayah) serta penuh rasa 
tanggung jawab (mas'uliyah). ${ }^{4}$

Corporate governance merupakan suatu konsepsi yang secara riil dijabarkan dalam bentuk ketentuan/peraturan yang dibuat oleh lembaga otoritas, norma-norma dan etika yang dikembangkan oleh asosiasi industri dan diadopsi oleh pelaku industri, serta lembaga-lembaga yang terkait dengan tugas dan peran yang jelas untuk mendorong disiplin, mengatasi dampak moral hazard, dan melaksanakan fungsi check and balance.

Penerapan sistem GCG dalam perbankan syariah diharapkan dapat meningkatkan nilai tambah bagi semua pihak yang berkepentingan (stakeholders) melalui beberapa tujuan berikut: 1) Meningkatkan efisiensi, efektifitas, dan kesinambungan suatu organisasi yang memberikan kontribusi kepada terciptanya kesejahteraan pemegang saham, pegawai dan stakeholders lainnya dan merupakan solusi yang elegan dalam menghadapi tantangan organisasi kedepan; 2) Meningkatkan legitimasi organisasi yang dikelola dengan terbuka, adil, dan dapat dipertanggungjawabkan; 3) Mengakui dan melindungi hak dan kewajiban para stakeholders; 4) Pendekatan yang terpadu berdasarkan kaidah-kaidah demokrasi, pengelolaan dan partisipasi organisasi secara legitimasi; 5) Mengendalikan konflik kepentingan yang mungkin timbul antar pihak prinsipal dengan agen; 6) Memimalkan biaya modal dengan memberikan sinyal positif untuk para penyedia modal. Meningkatkan nilai perusahaan yang dihasilkan dari biaya modal yang lebih rendah, meingkatkan kinerja keuangan dan persepsi yang lebih baik dari para stakeholders atas kinerja perusahaan di masa depan.

Dengan demikian melalui beberapa tujuan diatas, penerapan GCG pada bank syariah diharapkan semakin meningkatnya kepercayaan publik kepada bank syariah, pertumbuhan industri jasa keuangan Islam dan stabilitas sistem keuangan secara keseluruhan akan senantiasa terpelihara, dan keberhasilan industri jasa keuangan Islam dalam menerapkan GCG akan menempatkan lembaga keuangan Islam sejajar dengan lembaga keuangan internasional lainnya. Sejumlah perangkat dasar yang diperlukan untuk pembentukan GCG pada bank syariah antara lain: sistem pengendalian internal, manajemen risiko, transparansi bank, sistem akuntansi, pemurnian dan audit syariah, dan audit ekstern.

\section{Sistem Pengendalian Intern}

Kegiatan bank yang umumnya berhubungan dengan uang dalam jumlah yang sangat besar dapat menimbulkan resiko yang tinggi yang nantinya dapat mengakibatkan kerugian bagi bank. Maka, dalam melaksanakan kegiatannya bank perlu memperhatikan sistem pengendalian atau kontrol yang dimulai dari diri bank itu sendiri. Kontrol Internal dibutuhkan untuk mengakui dan menilai resiko, mendeteksi permasalahan dalam lembaga, serta mengoreksi kelemahan internal. Untuk dapat meyakinkan bahwa telah ada pengendalian diri tersebut perlu adanya suatu ukuran dan penilaian dari pihak yang tidak terkait dengan kegiatan tersebut (independen).

$4 \quad$ Nur Fakhrus Salis, "Penerapan dan Pengembangan Prinsip-Prinsip Syariah dalam Lembaga Keuangan Syariah" <https://cuplies.wordpress.com/2007/02/13/penerapan-dan-pengembangan-prinsip-\%E2\%80\%93-prinsip-syari\%E2\%80\%99ah-dalam-lembaga-keuangan-syari\%E2\%80\%99ah/> diunduh 15 Juni 2010. 
Yang dimaksud independen disini ialah pelaksanaan tugas dilakukan secara obyektif dan bebas dari tekanan dan kepentingan pihak manapun. Pelaksanaan tugas yang independen ini dilakukan oleh seorang auditor, auditor disini bertujuan untuk menentukan apakah kegiatan yang diperiksa sesuai dengan kondisi, peraturan, dan undang-undang tertentu. Karena yang diperiksa merupakan kegiatan internal bank maka auditor ini disebut dengan auditor Internal. ${ }^{5}$ Audit internal ini meliputi: a) Bagian Pengawasan Data, bagian ini sering juga disebut sebagai verificator, yaitu pemeriksa seluruh transaksi yang terjadi, dimana salah satu produknya adalah program zero defect, yaitu suatu program audit yang memberikan peringatan kepada pelaksana atas kesalahan-kesalahan pembukuan yang terjadi; b) Auditor Wilayah (Resident Auditor) dan Inspektur Pengawasan. Kedua pengawas ini berfungsi melakukan operasional audit, di samping audit keuangan. Titik berat audit yang dilakukan adalah pengujian secara menyeluruh atas berjalannya SPIN (Sistem Pengendalian Intern) yang antara lain meliputi: aspek organisasi, memadai tidaknya sumber daya insani, praktik bank yang sehat, dan unsur SPIN lainnya.

Hasil dari auditor ini berupa evaluasi/gambaran atas kondisi yang ada di lapangan dan praktik sehari-hari yang berlangsung dalam kegiatan bank. Auditor juga memberi masukan kepada manajemen dalam hal diperlukannya pembenahan, perbaikan, koreksi, baik yang menyangkut sumber daya insani, sistem prosedur, maupun aspek manajerial. ${ }^{6}$ Dalam kegiatannya sehari-hari, semua unsur pengawasan tetap tunduk dan patuh serta menjalankan Standar Pelaksanaan Fungsi Audit Intern Bank (SPAIB).

Penting kiranya fungsi dewan direksi lebih ditingkatkan untuk memastikan bahwa efektivitas sistem kontrol internal telah ditetapkan dan diawasi secara terus menerus. Ketika sistem tersebut telah ditetapkan, maka senior manajemen bertangung jawab untuk mengembangkan proses identifikasi, pengukuran, monitoring, dan kontrol terhadap risiko (meliputi risiko kredit, risiko negara dan transfer, risiko suku bunga, risiko pasar, risiko likuiditas, risiko opersional, risiko hukum, dan risiko reputasi) yang bisa mempengaruhi bank dalam mencapai tujuannya. Manajemen Risiko

Hal penting yang perlu dilakukan oleh bank syariah adalah membangun budaya manajemen risiko yang efektif, sehingga bank memiliki daya saing dan tetap bertahan dalam kondisi perekonomian yang penuh dengan ketidakpastian atau bahkan krisis. Macam-macam risiko yang dihadapi oleh bank syariah, antara lain sebagai berikut: 1) Risiko Pembiayaan, risiko ini muncul dari ketidakmampuan debitur untuk menunaikan kewajibannya yang telah jatuh tempo berdasarkan kesepakatan. Penyebab utama terjadinya risiko kredit adalah terlalu mudahnya bank memberikan pinjaman atau melakukan investasi karena terlalu dituntut untuk memanfaatkan kelebihan likuiditas. Akibatnya, penilaian kredit kurang cermat dalam mengantisipasi berbagai kemungkinan risiko usaha yang dibiayainya. 2) Risiko Likuiditas, risiko ini akan timbul ketika terjadi penurunan yang tidak diharapkan atas cash flow bersih

5 "Pengertian Audit", http://www.scribd.com/doc/11319454/Pengertian-Audit, diunduh 1 Juni 2010.

6 Muhammad Syafi'i Antonio, Bank Syariah: dari Teori ke Praktik, Jakarta: Gema Insani Press, 2001, h. 210. 
yang dimiliki oleh bank, dan pihak bank tidak mampu untuk mendapatkan sumber dana dengan biaya yang wajar dan sesuai dengan ketentuan syariah. Kondisi ini akan menyulitkan pihak bank untuk menunaikan kewajibannya yang akan jatuh tempo, di sisi lain bank juga tidak mampu menyalurkan pembiayaan pada peluang-peluang bisnis yang menguntungkan. Risiko likuiditas yang cukup tinggi memang akan memberikan keamanan bagi bank, namun hal ini akan berefek negatif bagi pencapaian tingkat profitabilitas bank. Dana bank akan banyak yang tidak tersalurkan dalam bentuk pembiayaan, sehingga bank tidak mendapatkan tambahan income yang selanjutnya akan berpengaruh pada rendahnya tingkat profitabilitas bank; 3) Risiko Tingkat Suku Bunga, risiko ini muncul akibat terjadinya fluktuasi pada harga beli dan harga jual yang dipengaruhi oleh perubahan situasi bisnis yang tidak bisa dikontrol. Transaksi bank syariah tidak bersentuhan dengan unsur bunga, maka ia tidak akan mengalami eksposur terhadap risiko perubahan tingkat suku bunga; 4) Risiko Operasional, risiko operasional muncul karena beberapa sebab. Salah satu penyebab utamanya adalah lemahnya sistem kontrol internal dan corporate governance. Kelemahan tersebut akan menciptakan kerugian finansial yang disebabkan karena adanya error, self-dealing, penyelewengan, atau gagalnya pemenuhan kewajiban secara tepat waktu dan efisien. Risiko operasional yang disebabkan oleh lemahnya sistem kontrol internal dan corporate governance akan mengakibatkan terjadinya penurnan net income ataupun cash flow dari target yang harus dicapai. Risiko operasional juga bisa disebabkan karena kegagalan teknologi, menurunnya reputasi bank atau ketidakpatuhan terhadap standar regulasi. Selain itu, resiko ini juga bisa muncul karena force majeur, seperti banjir, kebakaran, gempa, atau bencana lainnya. ${ }^{7}$

\section{Transparansi bank}

Adanya transparansi informasi didalam tubuh bank selain membantu bagi pemegang saham untuk tetap mempertahankan sahamnya atau menjualnya, atau bagi para deposan untuk tetap menyimpan dana atau menariknya dari bank bersangkutan. Juga akan membantu dewan direksi untuk mengetahui kinerja manajemen, bagi auditor eksternal berfungsi untuk mempersiapkan laporan yang akurat tentang usaha bank, bagi pengawas untuk memberikan saran dan rekomendasi atau tindakan koreksi terhadap kinerja yang menyimpang, sehingga keamanan, kenyamanan, dan reputasi bank dapat terjaga sebelum terlambat.

Bassel Committee mendefinisikan transparansi sebagai suatu kegiatan untuk menyampaikan informasi yang dapat dipercaya dan tepat waktu kepada publik, sehingga memungkinkan bagi para pengguna informasi untuk memanfaatkannya sesuai dengan kebutuhan, baik informasi yang terkait dengan kondisi keuangan dan kinerja bank, aktivitas bisnis, profil risiko, ataupun praktik manajemen resiko. Bassel Committee on Banking Supervision (BCBS) atau biasa disebut Komite Basel untuk Pengawasan Perbankan adalah suatu lembaga yang dibentuk oleh bank sentral dari negara-negara Group of Ten (G10) pada

$7 \quad$ Ibid, h. 75. 
tahun 1974. Keanggotaannya saat ini terdiri dari perwakilan senior dari otoritas pengawas perbankan dan bank sentral dari negara-negara G10 (Belgia, Kanada, Perancis, Jerman, Italia, Belanda, Swedia, Swiss, Britania Raya, Amerika Serikat) serta perwakilan dari Luxemburg dan Spanyol. Lembaga ini bertemu secara reguler empat kali dalam setahun, biasanya di markas Bank Penyelesaian Internasional (Bank for International Settlements, BIS) di Basel, Swiss, tempat sekretariat permanen dari 12 anggotanya. Komite Basel merumuskan standar dan pedoman pengawasan umum dan merekomendasikan praktik terbaik dalam pengawasan perbankan (seperti Basel II) dengan harapan bahwa negara-negara anggotanya serta negaranegara lain akan mengimplementasikan rekomendasi-rekomendasi tersebut ke dalam sistem nasional masing-masing. Tujuan komite ini adalah untuk mendorong konvergensi menuju pendekatan dan standar bersama dalam sektor perbankan. ${ }^{8}$

Transparansi akan dapat diraih jika pihak bank mampu menyediakan informasi yang relevan, akurat, tepat waktu, dan sesuai dengan definisi sebagaimana telah disebutkan. Transparansi merupakan faktor kunci yang berfungsi untuk menjaga efektivitas pengawasan terhadap keamanan, kenyamanan, dan reputasi bank.

\section{Sistem Akuntansi}

Standar akuntansi menjadi kunci sukses bank Islam dalam melayani masyarakat di sekitarnya sehingga, harus dapat menyajikan informasi yang cukup, dapat dipercaya, dan relevan bagi para penggunanya, namun tetap dalam konteks syariah islam. Salah satu prasyarat pengembangan kepercayaan itu adalah ketersediaan informasi yang meyakinkan nasabah terhadap kemampuan bank Islam dalam mencapai tujuannya. Diantara sumber-sumber informasi yang penting adalah laporan keuangan dari bank Islam yang disiapkan sesuai dengan standar yang dapat diterapkan pada bank Islam.

Dalam paradigma akuntansi Islam, bank syariah memiliki fungsi sebagai berikut: a) Manajemen Investasi, bank-bank Islam dapat melaksanakan fungsi ini berdasarkan kontrak mudharabah atau kontrak perwakilan; b) Investasi, bank-bank Islam menginvestasikan dana yang ditempatkan pada dunia usaha (baik dana modal maupun dana rekening investasi) dengan menggunakan alat-alat investasi yang konsisten dengan syariah. Misalnya adalah kontrak almurabahah, al-mudharabah, al-musyarakah, bai' as-salam, bai' al-ishtisna', al-ijarah, dan lain-lain; c) Jasa-jasa keuangan, bank Islam dapat juga menawarkan berbagai jasa keuangan lainnya berdasarkan upah (fee based) dalam sebuah kontrak perwakilan atau penyewaan. Contohnya garansi, transfer kawat, L/C, dan sebagainya; d) Jasa Sosial, konsep perbankan Islam mengharuskan bank Islam melaksanakan jasa sosial, bisa melalui dana qardh(pinjaman kebajikan), zakat, atau dana sosial yang sesuai dengan ajaran Islam. ${ }^{9}$

\section{Pemurnian dan Audit Syariah}

Tanggung jawab utama bank syariah adalah menciptakan kepercayaan bagi para deposan, serta meyakinkan bahwa operasionalnya telah sesuai dengan ketentuan syariah. Untuk

8 'Komite Basel', <http://id.wikipedia.org/wiki/Komite_Basel $\geq$, diunduh 31 Mei 2010.

9 Muhammad Syafi'i Antonio, Op.Cit., h. 201. 
memurnikan operasional bank sesuai dengan syariah, terdapat dua langkah utama yang harus dilakukan. Langkah pertama, memastikan bahwa semua produk yang ditawarkan oleh bank syariah telah sesuai dengan ketentuan dan opini dewan pengawas syariah. Langkah kedua, memberikan jaminan bahwa semua transaksi yang dilakukan oleh bank syariah telah sesuai dengan putusan dewan pengawas syariah.

\section{Audit eksternal}

Auditor eksternal di samping berperan untuk memastikan bahwa laporan keuangan bank telah disajikan secara profesional dan sesuai dengan standar laporan keuangan, ia juga harus memastikan bahwa keuntungan ataupun kerugian yang diungkapkan dalam laporan keuangan benar-benar merefleksikan kondisi bank sebenarnya, serta memastikan bahwa profit yang dihasilkan bukan dari usaha yang bertentangan dengan syariah. Auditor eksternal harus memiliki kompetensi profesional dalam hal auditing dan pemahaman tentang bank syariah. Suksesnya seorang auditor sangat bergantung pada kinerja audit internal, jika audit internalnya lemah, auditor eksternal mungkin akan sangat susah untuk menjalankan tugasnya secara efektif. Audit eksternal yang melakukan pemeriksaan antara lain Bank Indonesia, akuntan publik, maupun pihak lainnya. ${ }^{10}$

Beberapa hal yang secara khusus dilakukan dalam audit atas bank syariah, dapat disampaikan sebagai berikut: a) Di samping pengungkapan kewajaran penyajian laporan keuangan, juga diungkapkan unsur kepatuhan syariah; b) Perbedaan akunting yang menyangkut aspek produk, baik sumber dana maupun pembiayaan; c) Pemeriksaan ditribusi profit; d) Pengakuan pendapatan cash basis serta riil; e) Pengakuan beban yang secara acrual basis; f) Dalam hubungan dengan bank corresponden, khususnya corresponden depository, pengakuan pendapatan tetap harus menggunakan prinsip bagi hasil. Jika tidak, pendapatan atas bunga idak boleh dicatat sebagai pendapatan; g) Adanya pemeriksaan atas sumber dan penggunaan zakat; h) Revaluasi atas valuta asing dapat diakui apabila posisi devisa neto dalam posisi square. Dalam hal ini, harus ada ketentuan tentang suatu posisi PDN yang dianggap square; i) Ada tidaknya transaksi yang mengandung unsur-unsur yang tidak sesuai dengan syariah. ${ }^{11}$

Ditinjau secara yuridis bank syariah bertanggung jawab kepada banyak pihak (stakeholders). Pihak dimaksud antara lain terdiri dari nasabah penabung, pemegang saham, investor obligasi, bank koresponden, regulator, pegawai perseroan, pemasok serta masyarakat dan lingkungan. Dengan demikian penerapan GCG merupakan suatu kebutuhan bagi setiap bank syariah. Penerapan GCG merupakan wujud pertanggungjawaban bank syariah kepada masyarakat bahwa suatu bank syariah dikelola dengan baik, profesional dan hati-hati (prudent) dengan tetap berupaya meningkatkan nilai pemegang saham (shareholder's value) tanpa mengabaikan kepentingan stakeholders lainnya. Karena penerapan GCG ini merupakan sebuah bentuk pertanggungjawaban, maka bank syariah wajib menyampaikan laporan GCGnya baik

10 Ibid, h. 95.

11 Muhammad Syafi'i Antonio, Op.Cit., h. 212. 
kepada Bank Indonesia maupun kepada pemegang saham. Hal ini sebagai bentuk transparansi bank atas kondisi perusahaannya, seperti yang telah diatur didalam pasal 63 PBI No 11/33/ PBI/2009 tentang Pelaksanaan Good Corporate Governance Bagi Bank Umum Syariah dan Unit Usaha Syariah. Sehingga ketika bank melakukan pelanggaran atas ketentuan tersebut, akan dikenai sanksi sebagaimana diatur didalam Pasal 87 PBI No 11/33/PBI/2009 tentang Pelaksanaan Good Corporate Governance Bagi Bank Umum Syariah dan Unit Usaha Syariah.

Pelaksanaan prinsip-prinsip good corporate governance oleh sebuah bank, termasuk bank syariah paling tidak harus diwujudkan dalam: 1) Pelaksanaan tugas dan tanggung jawab Dewan Komisaris, Dewan Pengawas Syariah, dan Dewan Direksi; 2) Kelengkapan dan pelaksanaan tugas komite-komite dan satuan kerja yang menjalankan fungsi pengendalian intern bank; 3) Penerapan fungsi kepatuhan, auditor internal dan auditor eksternal; 4) Penerapan manajemen risiko, termasuk sistem pengendalian intern; 5) Penyediaan dana kepada pihak terkait dan penyediaan dana besar; 6) Rencana strategis bank; 7) Transparansi kondisi keuangan dan non keuangan Bank. ${ }^{12}$

Khusus untuk meningkatkan pemenuhan prinsip syariah oleh bank paling tidak terdapat dua langkah penting yang perlu ditempuh, yaitu: Pertama, perlunya mengefektifkan aturan dan mekanisme pengakuan (endorsement) dari otoritas fatwa dalam hal ini Dewan Syariah Nasional (DSN) dalam hal menentukan kehalalan atau kesesuaian produk dan jasa keuangan bank dengan prinsip syariah. Kedua, perlunya mengefektifkan sistem pengawasan yang memantau transaksi keuangan bank sesuai dengan fatwa yang dikeluarkan oleh otoritas fatwa perbankan. Terkait dengan hal ini permasalahan yang sering muncul adalah masih minimnya ahli yang memiliki pemahaman ilmu fikih dan syariah serta sekaligus memiliki pengetahuan perbankan yang memadai. ${ }^{13}$

Selain itu juga bagi para pemegang otoritas perbankan perlu mengantisipasi munculnya tantangan yang mungkin muncul terkait dengan implementasi GCG Bank Syariah di Indonesia. Untuk saat ini memang sebagian prinsip-prinsip GCG telah dipenuhi oleh bank-bank syariah, misalnya dengan telah dibentuknya aturan hukum dan kelembagaan khusus untuk bank syariah yang mengatur tentang struktur dan organisasi bank syariah, persyaratan pemilik dan pengurus, aturan dan mekanisme fit and proper test, kewajiban bank untuk membentuk satuan kerja audit intern, ketentuan disclosure, standard akutansi, dan penerapan manajemen risiko yang semuanya telah diatur secara detail dalam PBI No. 8/4/PBI/2006 tentang Pelaksanaan Good Corporate Governance Bagi Bank Umum.

Sebagai elemen pendukung bagi implementasi prinsip GCG pada bank syariah yakni adanya lembaga-lembaga lain, seperti Dewan Syariah Nasional (DSN), Dewan Pengawas Syariah (DPS), Lembaga Pengaduan Nasabah, Lembaga Mediasi Perbankan, Badan Arbitrase Syariah Nasional (BASYARNAS), dan terakhir adanya perluasan kewenangan yang dimiliki oleh pengadilan agama dalam hal memeriksa, memutus, dan menyelesaikan sengketa di bidang

${ }^{12}$ _www.tazkiaonline.com, Loc.Cit.

13 Ibid. 
ekonomi syariah sebagaimana yang diatur dalam Undang-Undang Nomor 3 Tahun 2006 tentang Perubahan Atas Undang-Undang Nomor 7 Tahun 1989 tentang Peradilan Agama (UU Peradilan Agama). Oleh karena itu, bank syariah perlu menerapkan GCG, karena bisa mempengaruhi penilaian dan menurunkan cost of capital, mempengaruhi kinerja bank, reputasi bank, dan pengambilan resiko bank, serta meminimalisasi risiko krisis keuangan, baik untuk bank secara individual maupun bagi sistem bank secara keseluruhan.

GCG dapat diimplementasikan secara terus menerus dan konsisten melalui lima tindakan, yakni: a) penetapan visi, misi, dan corporate values untuk memenuhi prinsip GCG; b) menyusun struktur corporate governance yang tepat; c) membangun corporate culture sesuai dengan nilai-nilai Islami; d) penentuan mekanisme public disclosures yang tepat dan akurat; e) serta penyempurnaan berbagai kebijakan bank syariah agar dapat memenuhi prinsip GCG.

Pada dasarnya, GCG adalah implementasi visi dan misi perbankan syariah. Poin utama yang menjadi acuan dari visi ini adalah memenuhi prinsip kehati-hatian (prudential banking). Sedangkan, poin misinya adalah mempersiapkan konsep serta melaksanakan pengaturan dan pengawasan berbasis risiko untuk menjamin kesinambungan operasi perbankan syariah yang sesuai dengan karakteristiknya. Implementasi GCG juga sangat memerlukan komitmen dan keterlibatan semua pihak, baik pihak internal maupun eksternal bank syariah. Melalui kerja sama yang harmonis dari seluruh elemen masyarakat, yang meliputi alim ulama, tokoh masyarakat, nasabah bank, akademisi, dan pemerintah, bank syariah dapat didorong untuk selalu mematuhi prinsip-prinsip GCG sehingga bisa membangun reputasi bank syariah sebagai uswatun hasanah dan dapat memberi kontribusi optimal dalam meningkatkan kesejahteraan masyarakat, mengurangi kemiskinan, dan pengangguran.

\section{Perbedaan Good Corporate Governance pada Bank Syariah Dengan Bank Konvensioanal}

Menurut Pasal 2 Undang-Undang Nomor 21 Tahun 2008 tentang Bank Syariah (UU No. 21/2008), perbankan syariah dalam melakukan kegiatan usahanya berasaskan prinsip syariah, demokrasi ekonomi,dan prinsip kehati-hatian. Dalam penjelasan Pasal 2 dikemukakan kegiatan usaha yang berasaskan berikut ini: ${ }^{14}$ 1) Prinsip syariah; 2) Demokrasi ekonomi yakni kegiatan ekonomi syariah yang mengandung nilai keadilan, kebersamaan, pemerataan, dan kemanfaatan; dan 3) Prinsip kehati-hatian adalah pedoman pengelolaan bank yang wajib dianut guna mewujudkan perbankan yang sehat, kuat dan efisien, sesuai dengan ketentuan peraturan perundang-undangan. Lebih lanjut prinsip syariah dijelaskan sebagai kegiatan usaha yang tidak mengandung unsur: a) riba, yaitu penambahan pendapatan secara tidak sah (batil) antara lain dalam transaksi pertukaran barang sejenis yang tidak sama kualitas, kuntitas, dan waktu penyerahan (fadhl), atau dalam transaksi pinjam-meminjam yang mempersyaratkan nasabah penerima fasilitas mengembalikan dana yang diterima melebihi pokok pinjaman karena berjalannya waktu (nasi'ah); b) maisir, yaitu transaksi yang digantungkan kepada suatu

\footnotetext{
${ }_{14}$ Adrian Sutedi, Perbankan Syariah : Tinjauan dan Beberapa Segi Hukum, Bogor: Ghalia Indonesia, 2009,
} h. 61 . 
keadaan yang tidak pasti dan bersifat untung-untungan; c) gharar, yaitu transaksi yang objeknya tidak jelas, tidak dimiliki, tidak diketahui keberadaannya, atau tidak dapat diserahkan pada saat transaksi dilakkan, kecuali diatur lain dalam syariah; d) haram, yaitu transaksi yang objeknya dilarang dalam syariah; e) zalim, yaitu transaksi yang menimbulkan ketidakadilan bagi pihak lainnya.

Berdasarkan prinsip-prinsip diatas maka perbedaan GCG syariah dan konvensional terletak pada syariah compliance yaitu kepatuhan pada syariah. Makna kepatuhan syariah dalam bank syariah secara konsep sesungguhnya adalah penerapan prinsip-prinsip Islam, syariah dan tradisinya kedalam transaksi keuangan dan perbankan serta bisnis lain yang terkait secara konsisten dan menjadikan syariah sebagai kerangka kerja bagi sistem dan keuangan bank syariah dalam alokasi sumber daya, manajemen, produksi, aktivitas pasar modal, dan distribusi kekayaan. ${ }^{15}$ Jaminan kepatuhan syariah (shari'a compliance assurance) atas keseluruhan aktivitas bank syariah merupakan hal yang sangat penting bagi nasabah dan masyarakat. Ada beberapa indikator yang dapat digunakan sebagai ukuran secara kualitatif untuk menilai kepatuhan syariah dalam bank syariah, antara lain sebagai berikut: 1) Akad atau kontrak yang digunakan untuk penyaluran dana sesuai dengan prinsip-prinsip dan aturan syariah yang berlaku; 2) Dana zakat dihitung dan dibayar serta dikelola sesuai dengan aturan dan prinsipprinsip syariah; 3) Seluruh transaksi dan aktivitas ekonomi dilaporkan secara wajar sesuai dengan standar akuntansi syariah yang berlaku; 4) Lingkungan kerja dan corporate culture sesuai dengan syariah; 5) Bisnis dan usaha yang dibiayai tidak bertentangan dengan syariah; 6) Terdapat dewan pengawas syariah sebagai pengarah syariah atas keseluruhan aktivitas operasional bank syariah; 7) Sumber dana berasal dari sumber dana yang sah dan halal menurut syariah $^{16}$

Indikator-indikator tersebut diatas merupakan prinsip-prinsip umum yang menjadi acuan umum bagi manajemen bank syariah dalam mengoperasikan bank syariah. Kepatuhan syariah dalam operasional bank syariah dinilai berdasarkan indikator-indikator tersebut diatas, yaitu apakah operasional bank telah dilaksanakan sesuai dengan indikator umum kepatuhan syariah tersebut.

Selain kepatuhan pada syariah, dilihat dari struktur organisasi bank syariah, unsur yang membedakan dengan bank konvensional adalah adanya keharusan bank syariah memiliki Dewan Pengawas Syariah (DPS). DPS ini bertugas untuk mengawasi operasional bank dan produkproduk bank syariah agar sesuai dengan prinsip syariah. Hal ini karena transaksi-transaksi yang berlaku dalam bank syariah sangat khusus jika dibandingkan bank konvensional. DPS harus membuat pernyataan secara berkala (biasanya tiap tahun) bahwa bank yang diawasinya telah berjalan sesuai dengan ketentuan syariah. Pernyataan ini dimuat dalam laporan tahunan (annual report) bank bersangkutan. Tugas lain DPS adalah meneliti dan membuat rekomendasi produk baru dari bank yang diawasinya. Dengan demikian, DPS bertindak sebagai penyaring pertama

\footnotetext{
15 Ibid, h. 145.
}

16 Ibid, h. 146. 
sebelum suatu produk diteliti kembali dan difatwakan oleh Dewan Syariah Nasional (DSN). ${ }^{17}$ Selain DPS, Majelis Ulama Indonesia memiliki Dewan Syariah Nasional (DSN), fungsi utama DSN adalah mengawasi produk-produk lembaga keuangan syariah agar sesuai dengan syariah Islam. Untuk keperluan pengawasan tersebut, DSN membuat garis panduan produk syariah yang diambil dari sumber-sumber hukum Islam. Fungsi lain dari DSN adalah meneliti dan memberi fatwa bagi produk-produk yang dikembangkan oleh lembaga keuangan syariah. ${ }^{18}$ Panduan DSN ini menjadi pedoman bagi DPS untuk melakukan pengawasan terhadap produkproduk bank. Hal-hal tersebut diatas inilah yang tidak dimiliki oleh perbankan konvensional sehingga menjadi pembeda dengan bank syariah.

\section{Kesimpulan}

Bahwa konsep Good Corporate Governance antara Bank Konvensional dengan bank syariah pada dasarnya adalah sama, namun yang menjadi pembeda diantara keduanya ialah adanya syariah compliance yaitu kepatuhan pada syariah, kemudian adanya Dewan Pengawas Syariah (DPS) yang bertugas meneliti dan membuat rekomendasi produk baru dari bank yang diawasinya serta melakukan pengawasan terhadap bank syariah bahwa kegiatan usaha yang dilakukannya mematuhi prinsip syariah sebagaimana telah ditentukan oleh fatwa dan syariah Islam. Serta adanya Dewan Syariah Nasional yang fungsi utamanya adalah mengawasi produkproduk lembaga keuangan syariah agar sesuai dengan syariah Islam.

\section{Daftar Pustaka}

\section{Buku}

Edy Wibowo dan Untung Hendy Widodo, Mengapa Memilih Bank Syariah?, Bogor: Ghalia Indonesia, 2005.

Muhammad Syafi'i Antonio, Bank Syariah: dari Teori ke Praktik, Jakarta: Gema Insani Press, 2001.

Adrian Sutedi, Perbankan Syariah : Tinjauan dan Beberapa Segi Hukum, Bogor: Ghalia Indonesia, 2009.

\section{Internet}

Anonim, "Pengertian Audit", <http://www.scribd.com/doc/11319454/Pengertian-Audit> , diakses tanggal 1 Juni 2010.

Firani, "Menjadi Lebih Baik Dengan Good Corporate Governance pada Perbankan",<http:// banking.blog.gunadarma.ac.id/2009/04/29/menjadi-lebih-baik-dengan-good-corporate governance-pada-perbankan/> , diakses tanggal 04 November 2009.

Thomas S. Kaihatu, "Good Corporate Governance dan Penerapannya di Indonesia,">http://

\footnotetext{
17 Muhammad Syafi'i Antonio, Op.Cit., h. 234.

18 Ibid., h. 236.
} 
puslit2.petra.ac.id/ejournal/index.php/man/article/viewFile/16505/16497>, diakses tanggal 1 juni 2010.

Nur Fakhrus Salis, "Penerapan dan Pengembangan Prinsip-Prinsip Syariah dalam Lembaga Keuangan Syariah" <https://cuplies.wordpress.com/2007/02/13/penerapan-danpengembangan-prinsip-\%E2\%80\%93-prinsip-syari\%E2\%80\%99ah-dalam-lembagakeuangan-syari\%E2\%80\%99ah/, diakses tanggal 15 Juni 2010. 